\title{
HUBUNGAN SUMBER DAYA DENGAN KESIAPSIAGAAN PETUGAS DALAM MENGHADAPI KEJADIAN LUAR BIASA DBD PUSKESMAS BIRU KAB.BONE
}

\author{
NAJMAN \\ AKPER Batari Toja Watampone \\ Alamat korespondensi : (Najman@bataritoja.ac.id/085240644001)
}

\begin{abstract}
ABSTRAK
Deman Berdarah Dengue (DBD) merupakan salah satu penyakit menular yang menjadi prioritas masalah kesehatan karena sering menimbulkan Kejadian Luar Biasa (KLB) sehingga perlu ada persiapan atau kesiapsiagaan untuk mencegah atau mengurangi dampak yang ditimbulkan. Penelitian ini bertujuan untuk mengetahui hubungan antara pengetahuan, sikap, sarana dan dana dengan Kesiapsiagaan Petugas kesehatan Puskesmas Biru Kabupaten Bone dalam menghadapi Kejadian Luar Biasa Deman berdarah Dengue (DBD) diwilayah kerjanya. Penelitiani ini merupakan penelitian survei analitik dengan pendekatan cross sectional study. Pengambilan sampel dilakukan dengan cara total sampling dari keseluruhan petugas kesehatan Puskemas $(n=60)$. Data dianalisis secara statistik dengan menggunakan uji Chi-Square koreksi Fisher's Exact Test dengan koefisien $\alpha=0,05$. Hasil penelitian menunjukkan bahwa pada variabel pengetahuan didapatkan nilai $p=0,016(p=<0,05)$, dan variabel sikap dengan nilai $p=0,006 \quad(p=<0,05)$. Hal terebut berarti bahwa terdapat hubungan yang signifikan antara pengetahuan dan sikap dengan kesiapsiagaan petugas kesehatan Puskesmas Biru Kabupaten Bone, sedangkan variabel sarana didapatkan nilai $p=0,092(p=>0,05)$ dan variabel dana dengan nilai $p=0,512(p=>0,05)$, hal tersebut berarti bahwa tidak terdapat hubungan yang signifikan antara sarana dan dana dengan kesiapsiagaan petugas kesehatan Puskesmas Biru Kabupaten Bone dalam menghadapi Kejadian Luar Biasa DBD diwilayah kerjanya. Pengetahuan dan sikap merupakan dua faktor yang berperan penting terhadap kesiapsiagaan petugas kesehatan. Semakin baik pengetahuan dan sikap petugas kesehatan, semakin baik pula tingkat kesiapsiagaannya dalam menghadapi Kejadian Luar Biasa DBD.
\end{abstract}

Kata Kunci: Kesiapsiagaan, Kejadian Luar Biasa, Dengue Hemorrage Fever (DBD)

\section{PENDAHULUAN}

Deman Berdarah Dengue (DBD) merupakan salah satu penyakit menular yang masih menjadi prioritas masalah kesehatan mengingat sering menimbulkan bencana Kejadian Luar Biasa dan dapat menyebabkan kematian. Penyakit ini disebabkan oleh virus dengue yang disebarkan oleh nyamuk Aedes aegypti sebagai vektor utama. Jumlah penderita dan luas daerah penyebarannya semakin bertambah seiring dengan meningkatnya mobilitas dan kepadatan penduduk (Kemenkes, 2010). Di Indonesia sendiri demam berdarah dengue (DBD) merupakan masalah kesehatan masyarakat, karena angka kesakitan semakin meningkat, dan sering menimbulkan kematian serta Kejadian Luar Biasa (KLB) yang berulangulang, (Khasanah, 2016).

Menurut WHO, sekitar 2,5-3 milyard manusia yang hidup di 112 negara tropis dan subtropis berada dalam keadaan terancam infeksi dengue. Setiap tahunnya sekitar 50100 juta penderita dengue dan 500.000 penderita deman berdarah dengue dilaporkan oleh WHO di seluruh dunia, dengan jumlah kematian sekitar 22.000 jiwa, terutama pada anak-anak. Pada 25 tahun terakhir terjadi penyebaran global yang luas dari epidemi Deman Dengue/ Deman Berdara Dengue. Hal ini disebabkan oleh urbanisasi yang tidak terencana dengan baik dibanyak negaranegara tropis yang sedang berkembang, transportasi yang cepat dan moderen, serta pemberantasan nyamuk Aedes yang tidak efektif (Soedarto, 2012).

Penelitian sebelumnya yang dilakukan oleh Mirzana dkk (2014), dari hasil uji chisquare menunjukkan bahwa terdapat hubungan antara pengetahuan dengan nilai $p=0,023 \quad(p<0,05)$ dan sikap dengan nilai $p=0,010 \quad(p<0,05) \quad$ dengan kesiapsiagaan keluarga dalam menghadapi Kejadian Luar Biasa DBD. Selain pengetahuan dan sikap, faktor lain yang juga dapat berhubungan dengan kesiapsiagaan dalam menghadapi Kejadian Luar Biasa DBD adalah tersedianya dana oprasional yang cukup serta sarana yang memadai. 
Menurut data yang diperoleh Jumlah penderita DBD di wilayah kerja Puskesmas Biru tahun 2014 sebanyak 167 orang meningkat dari tahun sebelumnya sebanyak 91 orang, sementara tahun 2015 jumlah penderita turun menjadi 140 orang dengan 4 orang meninggal, kemudian pada tahun 2016 jumlah penderita meningkat lagi menjadi 185 orang dan 3 orang meninggal, sehingga dalam 3 tahun terakhir kasus DBD di wilayah kerja Puskesmas Biru ditetapkan sebagai Kejadian Luar Biasa. Petugas pelaksana P2M Puskesmas Biru mengatakan bahwa kesiapsiagaan petugas kesehatan Puskesmas Biru Kabupaten Bone dalam menghadapi KLB DBD masih tergolong rendah, hal ini disebabkan karena masih rendahnya kualitas dan kuantitas sumber daya Puskesmas sehingga pelaksanaan program pengendalian penyakit DBD belum berjalan optimal. Gerakan PSN dengan 3M plus dimasyarakat juga belum berjalan optimal karena kurannya kesadaran masyarakat yang menganggap bahwa pemberantasan penyakit DBD adalah tugas dan tanggung jawab petugas kesehatan Puskesmas (Puskesmas Biru, 2016).

\section{BAHAN DAN METODE}

Lokasi, Populasi, Sampel

Penelitian ini dilaksanakan di Puskesmas Biru Kab. Bone dimulai bulan juliAgustus tahun 2017. Populasi pada penelitian ini adalah Seluruh Petugas kesehatan dilingkungan puskesmas Biru Kab. Bone. Sampel pada penelitian ini adalah sampel yang masuk dalam kriteria Inklusi dan Eksklusi diperoleh sebanyak 60 sampel.

1. kriteria inklusi:
a. Petugas/tenaga Kesehatan Puskesmas yang masih aktif
b. Petugas Kesehatan Puskesmas yang bersedia menjadi responden

2. kriteria eksklusi:
a. Petugas Puskesmas yang bukan merupakan tenaga kesehatan Puskesmas Biru.
b. Tidak mampu berkomunikasi dengan baik atau sakit

\section{Pengumpulan Data}

1. Data sekunder adalah data yang diperoleh dalam bentuk dokumen-dokumen yang ada di Puskesmas Biru.

2. Data yang diperoleh dari responden (sampel) langsung melalui wawancara berpedoman pada kuesioner yang telah disiapkan, pengamatan (observasi) dengan menggunakan instrument daftar cek (checklist).

\section{Pengolahan Data}

1. Editing

Editing adalah tahapan kegiatan memeriksa validitas data yang masuk seperti memeriksa kelengkapan pengisian kuesioner, kejelasan jawaban, relevansi jawaban dan keseragaman suatu pengukuran.

2. Coding

Coding adalah tahapan kegiatan mengklasifikasi data dan jawaban menurut kategori masing-masing sehingga memudahkan dalam pengelompokan data.

3. Processing

Processing adalah tahapan kegiatan memproses data agar dapat dianalisis. Pemrosesan data dilakukan dengan cara memasukkan data hasil pengisian kuesioner ke dalam master tabel.

4. Cleaning

Cleaning yaitu tahapan kegiatan pengecekan kembali data yang sudah di masukkan dan melakukan koreksi bila terdapat kesalahan. (Hidayat, 2013).

\section{Analisis Data}

1. Analisis Univariat yaitu analisis variabel independen dalam bentuk distribusi frekuensi dan dihitung persentasenya.

2. Analisis Bivariat yaitu tabulasi silang antara dua variabel yaitu variabel independen dan dependen. Analisis bivariat yang digunakan untuk mengetahui hubungan terhadap objek penelitian adalah menggunakan uji chi square dengan koefisien $\alpha=0,05$.

\section{HASIL PENELITIAN}

1. Analisis Univariat

Tabel 1 Distribusi karakteristik responden Petugas Puskesmas Biru Kab. Bone( $\mathrm{n}=60)$

\begin{tabular}{|c|c|c|}
\hline Karakteristik & $\mathrm{n}$ & $\%$ \\
\hline $\begin{array}{c}\text { Usia } \\
\text { Dewasa muda } \\
(\leq 40 \text { thn) } \\
\text { Dewasa Tua } \\
(>40 \text { thn) }\end{array}$ & 46 & 76,7 \\
\hline $\begin{array}{c}\text { Jenis kelamin } \\
\text { Laki-Laki }\end{array}$ & 8 & 23,3 \\
Perempuan & 52 & 13,3 \\
\hline Pendidikan & 26,7 \\
Rendah & 2 & 3,3 \\
Sedang & 25 & 41,7 \\
Tinggi & 33 & 55 \\
\hline
\end{tabular}

Dari tabel 1 menunjukkan dari 60 responden lebih banyak responden yang berada pada rentang usia dewasa muda yaitu sebanyak 46 orang (376,7\%), yang berusia antara $\leq 40$ tahun. Berdasarkan jenis kelamin yang paling banyak adalah 
berjenis kelamin perempuan, yaitu dengan jumlah 52 responden $(86,7 \%)$, dan jenis kelamin laki-laki yaitu berjumlah 8 responden (13,3\%). Berdasarkan Pendidikan Responden paling banyak adalah berpendidikan tinggi yaitu 33 orang $(55 \%)$

2. Analisis Bivariat

Tabel 2 Hubungan antara pengetahuan dengan kesiapsiagaan Petugas Puskesmas Biru 2017

\begin{tabular}{|c|c|c|c|c|c|c|}
\hline \multirow{2}{*}{$\begin{array}{c}\text { Pengetahua } \\
\mathrm{n}\end{array}$} & \multicolumn{4}{|c|}{ Kesiapsiagaan } & \multicolumn{2}{c|}{ Total } \\
\cline { 2 - 7 } & Siapsiaga & $\begin{array}{c}\text { Tidak } \\
\text { siapsiaga }\end{array}$ & \multicolumn{2}{c|}{} \\
\cline { 2 - 7 } & $\mathrm{n}$ & $\%$ & $\mathrm{n}$ & $\%$ & $\mathrm{n}$ & $\%$ \\
\hline Baiik & 6 & 66,7 & 12 & 23,5 & 18 & 30 \\
\hline Kurang & 3 & 33,3 & 39 & 76,5 & 42 & 70 \\
\hline Total & 9 & 100 & 51 & 100 & 60 & 100 \\
\hline \multicolumn{6}{|c|}{$p=0,16$} \\
\hline
\end{tabular}

Berdasarkan tabel 2, diketahui dari 9 orang $(15 \%)$ responden dalam kategori siapsiaga, terdapat 6 orang $(66,7 \%)$ yang mempunyai pengetahuan baik, dan 3 orang $(33,3 \%)$ lainnya dengan pengetahuan kurang. Sedangkan Dari 51 (85\%) responden dengan kategori tidak siapsiaga, terdapat 12 orang $(23,5 \%)$ yang mempunyai pengetahuan baik, dan 39 orang $(76,5 \%)$ lainnya dengan pengetahuan kurang.

Berdasarkan hasil uji statistik chisquare dengan koreksi fisher's exact test diperoleh nilai $p=0,016(p<\alpha=0,05)$ yang menunjukkan bahwa terdapat hubungan yang bermakna. Dengan demikian perbedaan tingkat kesiapsiagaan petugas kesehatan antara pengetahuan yang baik dengan pengetahuan kurang dalam menghadapi Kejadian Luar Biasa DBD di Puskesmas Biru Kabupaten Bone secara statistik bermakna.

Tabel 3 Hubungan antara sikap dengan kesiapsiagaan Petugas Puskesmas Biru 2017

\begin{tabular}{|c|c|c|c|c|c|c|}
\hline \multirow{3}{*}{ Sikap } & \multicolumn{4}{|c|}{ Kesiapsiagaan } & \multicolumn{2}{c|}{ Total } \\
\cline { 2 - 6 } & Siapsiaga & \multicolumn{2}{|c|}{$\begin{array}{c}\text { Tidak } \\
\text { siapsiaga }\end{array}$} & \multicolumn{2}{c|}{} \\
\cline { 2 - 6 } & $\mathrm{n}$ & $\%$ & $\mathrm{n}$ & $\%$ & $\mathrm{n}$ & $\%$ \\
\hline Positif & 7 & 77,8 & 14 & 27,5 & 21 & 35 \\
\hline Negatif & 2 & 22,2 & 37 & 72,5 & 39 & 65 \\
\hline Total & 9 & 100 & 51 & 100 & 60 & 100 \\
\hline \multicolumn{8}{|c|}{$p=0,006$} \\
\hline
\end{tabular}

Berdasarkan tabel 3, diketahui dari 9 orang $(15 \%)$ responden dalam kategori siapsiaga terdapat 7 orang $(77,8 \%)$ yang mempunyai sikap positif, dan 2 orang $(22,2 \%)$ lainnya mempunyai sikap negatif. Sedangkan Dari 51 orang (85\%) responden dengan kategori tidak siapsiaga, terdapat 14 orang $(27,5 \%)$ mempunyai sikap positif, dan 37 orang $(72,5 \%)$ lainnya mempunyai sikap negatif.

Berdasarkan hasil uji statistik chisquare dengan koreksi fisher's exact test diperoleh nilai $p=0,006(p<\alpha=0,05)$ yang menunjukkan bahwa terdapat hubungan yang bermakna. Dengan demikian perbedaan tingkat kesiapsiagaan petugas kesehatan antara sikap yang baik/positif dengan sikap tidak baik/negatif dalam menghadapi Kejadian Luar Biasa DBD di Puskesmas Biru Kabupaten Bone secara statistik bermakna.

\section{PEMBAHASAN}

1. Hubungan antara pengetahuan dengan kesiapsiagaan Petugas Puskesmas Biru 2017

Hasil penelitian ini menunjukkan bahwa terdapat hubungan yang bermakna antara pengetahuan dengan kesiapsiagaan petugas kesehatan Puskesmas Biru Kabupaten Bone dalam menghadapi Kejadian Luar Biasa DBD di wilayah kerjanya dengan nilai $p=0,016 \quad(p<\alpha=0,05)$. Hasil tersebut menunjukkan ada perbedaan yang signifikan kesiapsiagaan antara responden yang pengetahuannya baik dengan responden yang pengetahuannya kurang.

Hasil penelitian tersebut sejalan dengan penelitian yang dilakukan oleh Mirzanah dkk (2014), yang mengatakan pengetahuan merupakan faktor utama kunci kesiapsiagaan. Hasil uji chi-square didapatkan nilai $p=0,023$, yang menunjukkan bahwa ada hubungan pengetahuan dengan kesiapsiagaan keluarga dalam menghadapi KLB DBD.

Menurut Sutton \& Tierney (2006), pengetahuan dapat mempengaruhi kesiapsiagaan untuk menghadapi bencana. Penelitian yang dilakukan Ginting dkk (2013), yang menggunakan uji chi-square menemukan ada hubungan antara pengetahuan dengan kinerja petugas surveilans Demam Berdarah Dengue di Kota Pematang Siantar dengan nilai $p=$ $0,007(p<0,05)$. Firmansyah dkk (2014), dalam penelitiannya menyatakan bahwa hubungan pengetahuan dengan perilaku kesiapsiagaan terhadap bencana banjir dan longsor menunjukkan hubungan yang kuat dan berpola positif artinya semakin bertambah pengetahuan semakin tinggi perilaku kesiapsiagaannya.

Pengetahuan merupakan faktor penting yang dapat mempengaruhi 
kesiapsiagaan petugas kesehatan dalam menghadapi Kejadian Luar Biasa DBD. Semakin baik pengetahuan petugas kesehatan, semakin baik pula tingkat kesiapsiagaannya dalam menghadapi Kejadian Luar Biasa DBD, karena pengetahuan yang baik merupakan domain penting terbentuknya perbuatan yang baik. Oleh sebab itu pendidikan dan pelatihan petugas kesehatan perlu dilakukan untuk meningkatkan pengetahuan dan kompetensinya sehingga mereka lebih waspada dan siapsiaga.

2. Hubungan antara Sikap dengan kesiapsiagaan Petugas Puskesmas Biru 2017

Hasil penelitian ini menunjukkan bahwa terdapat hubungan yang bermakna antara sikap dengan kesiapsiagaan petugas kesehatan Puskesmas Biru Kabupaten Bone dalam menghadapi Kejadian Luar Biasa DBD di wilayah kerjanya dengan nilai $p=0,006(p<\alpha=0,05)$. Hasil tersebut menunjukkan ada perbedaan yang signifikan kesiapsiagaan antara responden yang memiliki sikap baik/positif dengan responden yang memilki sikap negatif.

Hasil tersebut sejalan dengan penelitian yang dilakukan oleh Mirzana dkk (2014), yang mengatakan bahwa kesiapsiagaan keluarga dalam menghadapi bencana dapat dipengaruhi oleh sikap yang positif. Hasil uji chi-square didapatkan nilai $p=0,010$, yang menunjukkan bahwa ada hubungan sikap dengan kesiapsiagaan keluarga dalam menghadapi KLB DBD. Sikap positif yang dimiliki biasanya dapat memengaruhi kepedulian individu dan rumah tangga untuk siapsiaga dalam mengantisipasi Kejadian Luar Biasa DBD, terutama bagi yang bertempat tinggal di daerah rawan.

Menurut Moenir (2006), yang menyatakan bahwa sikap adalah suatu pandangan atau ketetapan hati seseorang terhadap suatu objek yang akan diikuti dengan perbuatan setelah ada rangsangan untuk berbuat. Menurut Azwar (1996), menyatakan bahwa sikap yang positif terhadap sesuatu mencerminkan perilaku yang positif. Penelitian yang dilakukan oleh Gulton (2012), yang mengatakan sikap petugas kesehatan mengenai kesiapsiagaan menghadapi bencana banjir dari 22 responden, 21 responden $(95,5 \%)$ menyatakan mendukung atau bersikap positif mengenai kegiatan kesiapsiagaan tenaga kesahatan menghadapi banjir dan mendukung setiap upaya-upaya penanggulangan bencana banjir di bidang kesehatan.

Sikap merupakan salah satu indikator penting dalam kesiapsiagaan menghadapi Kejadian Luar Biasa DBD. Semakin baik/positif sikap petugas kesehatan maka semakin baik pula kesiapsiagaannya untuk menghadapi Kejadian Luar Biasa DBD, karena sikap positif dapat mendorong perilaku positif. Oleh sebab itu perlu dilakukan upaya-upaya untuk menumbuhkan sikap positif dengan meningkatkan pengetahuan dan pemahaman petugas kesehatan Puskesmas melalui pendidikan atau pelatihan karena dengan pengetahuan yang baik akan menumbuhkan sikap yang baik/positif serta rasa kepedulian dan tanggungjawab sehingga petugas kesehatan lebih waspada dan siapsiaga.

\section{KESIMPULAN}

1. Kesiapsiagaan petugas kesehatan Puskesmas Biru Kabupaten Bone dalam menghadapi Kejadian Luar Biasa DBD diwilayah kerjanya, masih perlu ditingkatkan

2. Terdapat hubungan yang bermakna antara pengetahuan yang baik dengan kesiapsiagaan petugas kesehatan Puskesmas Biru Kabupaten Bone, dimana semakin baik pengetahuan petugas kesehatan semakin baik pula kesiapsiagaannya dalam menghadapi kejadian luar biasa DBD, karena pengetahuan yang baik merupakan domain penting untuk terbentuknya suatu perbuatan baik.

3. Terdapat hubungan yang bermakna antara sikap yang baik/positif dengan kesiapsiagaan petugas kesehatan Puskesmas Biru Kabupaten Bone, dimana semakin baik/positif sikap petugas kesehatan semakin baik pula perilaku kesiapsiagaan petugas tersebut dalam menghadapi kejadian luar biasa DBD, karena sikap positif akan mendorong terbentuknya perilaku positif.

\section{SARAN}

1. Perlu ada komitmen dari Dinas Kesehatan Kabupaten Bone untuk meningkatkan kapasitas kesiapsiagaan dalam menghadapi Kejadian Luar Biasa DBD dengan memberikan pendikan atau pelatihan pada petugas kesehatan tentang manajemen penanggulangan bencana Kejadian Luar Biasa DBD secara berkelanjutan. 
2. Diharapkan ada upaya-upaya untuk meningkatkan kualitas dan kuantitas sumber daya Puskesmas untuk kesiapsiagaan menghadapi Kejadian Luar Biasa DBD dengan mengikut sertakan petugas kesehatan Puskesmas dalam pendikan atau pelatihan penanggulangan Kejadian Luar Biasa DBD.
3. Diharapkan kedepannya ada penelitian lebih lanjut dan lebih mendalam terkait dengan topik penelitian ini ataupun faktorfaktor lain yang dapat mempengaruhi atau berhubungan dengan kesiapsiagaan petugas kesehatan dalam menghadapi Kejadian Luar Biasa DBD.

\section{DAFTAR PUSTAKA}

Firmansyah I. dkk. (2014). Hubungan Pengetahuan Dengan Perilaku Kesiapsiagaan Dalam Menghadapi Bencana Banjir Dan Longsor Pada Remaja Usia 15-18 Tahun Di Sma Al-Hasan Kemiri Kecamatan Panti Kabupaten Jember. e-journal. Universitas Jember.

Ginting M. dkk. (2013). Analisis Determinan Kinerja Petugas Surveilans Deman Berdarah Dengue. Analitik : Kota Pematan Siantar (Tesis). Sumatera Utara: Program Pasca Sarjana FKM-USU

Gultom B.A. (2012). Pengaruh Pengetahuan dan Sikap Terhadap Kesiapsiagaan Tenaga Kesehatan Puskesmas Kampung Baru Menghadapi Bencana Banjir di Kecamatan Medan Maimun. e-journal. Universitas Sumatera Utara.

Hidayat. 2013. Metode Penelitian Keperawatan dan Teknik Analisa Data. Jakarta: Salemba Medika

Khasanah. (2016). Disaster Manajemen Plan Kejadian Luar Biasa Deman Berdarah Dengue. (online). diakses 23 Februari 2017.

Mirzana N. dkk. (2014). Kajian Kesiapsiagaan Keluarga Dalam Menhadapi Kejadian Luar Biasa DBD di Kecamatan Jaya Baru Kota Banda Aceh. Jurnal Kedokteran Universitas Syiah Kuala. Vol.14 No.1

Moenir H.A.S. (2006). Manajemen Pelayanan Umum di Indonesia. Edisi I. Cetakan 7. Jakarta: Bumi aksara.

Soedarto. (2012). Deman Berdarah Dengue. Jakarta: Sagung Seto. 